\title{
ON SOME DEFINITE COMPOUNDS OF PROTEIN-BODIES.
}

By ThOMAS B. OSBORxE.

Received May 18,1899 .

PROTEIN-BODIES, as hitherto prepared in a state fit for the considered to be, for the most part, distinct organic molecules, not united to either acids or bases.

Although protein-bodies are known to combine or react with acids, bases and halogens, scarcely any of their compounds or derivatives have been as yet described of constant or definite composition, except in cases where the original substance has been profoundly modified or broken up.

The object of this notice is to state briefly some results of an investigation which leads to the conclusion that protein-bodies, as hitherto prepared, are, in fact, definite chemical compounds of protein-substance with common mineral acids, or contain such compounds in admixture.

A large number of the purest protein-preparations that it has hitherto been possible to make in this laboratory, including egg albumin several times recrystallized, edestin, legumin, excelsin, amandin, corylin, phaseolin, gliadin, hordein and zein, ${ }^{\prime}$ are, without exception, acid to phenolphthalein, slightly acid or neutral to litmus and decidely alkaline to lacmoid.

To render gram portions of the above-named substances neutral to litmus has required in some cases not any, in others from one-tenth cc. to one cc., and in a very few instances a little more than one cc. of decinormal alkali solution. To make the same gram portions netutral to phenolphthalein, a further quantity of about one cc. of decinormal alkali has been required, except for legumin, which took up about two cc.

By help of lacmoid and other indicators, it can be shown that these protein-bodies are able to combine with additional quantities of acids.

In case of edestin preparations, ${ }^{2}$ that had been deposited from

I See papers by the author and his associates in $\mathrm{Am}$. Chem. $J$, I3, 14 and 15 . This Journal, 16, 17, I8, 19, and 20. Also Griessmayer, Die Protiede, etc., Heidelberg, 1897.

2 Edestin is one of several crystallized substances which are frequently termed plant-vitellin. It was first prepared by Barbieri from squash seeds, and was obtained in distinct crystals by Gribler. It was afterwards extracted from seeds of hemp, castor bean and sunflower, by Ritthausen. ( $J$ prakt. Chem., (2) 18, 102; 23, 97 aud 481.) The author and his associates bave identified it in the seeds of flax, cotton, wheat, rye, barley, and maize. See also $A m$. Chem. J.. 14,671 ; this Journal, I8,609. 
salt solutions, I have undertaken to determine what acids are present which thus react with an alkali.

When such an edestin preparation is suspended in water and made neutral to phenolphthalein, edestin itself, pure and simple, remains undissolved, while the added alkali carries into solution its equivalent of the acid or acids which had been united to the edestin.

What acids are thus removed from edestin depends upon the conditions of its preparation, that acid being predominant which was most abundant as a mineral salt in the solution from which the edestin last separated.

Accordingly, edestin that has been precipitated from sodium chloride brines carries with it hydrochloric acid chiefiy, but, when thrown down from ammonium sulphate solutions, it is united to sulphuric acid. It appears to be also in small part combined to an organic acid, as yet unidentified, whose alkali salt yields carbonate when ignited.

The smallest quantities of alkali carbonate and, therefore, it is to be inferred of organic acid, have come from those preparations which have been repeatedly deposited out of sodium chloride brine.

The solutions hitherto obtained on thus neutralizing edestin preparations with alkali, have invariably contained a very little organic matter which when strongly heated gives out a peculiar characteristic odor and yields alkaline vapors.

Property of Edestin.-Before giving further account of edestin compounds, it is best to state explicitly some of the characters of edestin itself.

As before mentioned, when preparations which contain edestin chemically united to acids are suspended in a little water and made exactly neutral to phenolphthalein by addition of dilute solution of potassium hydroxide, the edestin remains undissolved, and after washing with pure water is, so far as we have been able to discover, entirely free from the acids that were combined with it.

Thus isolated edestin is insoluble in pure water, but dissolves readily in decinormal alkali and also in decinormal hydrochloric acid. Of the alkali seven-tenths $c c$. and of the acid one and 
four-tenths cc. are required to effect the solution of one gram of water-free edestin.

Pure edestin dissolves freely in a ten per cent. brine of pure sodium chloride. This solution, freshly prepared, is neutral to phenolphthalein, but alkaline to litmus and strongly alkaline to lacmoid. When this solution is heated to $99^{\circ}$ in a boiling waterbath, it is very slowly and imperfectly coagulated.

Solution of edestin in ten per cent. brine, when saturated with sodium chloride, is precipitated slightly; when saturated with magnesium sulphate, it is precipitated more largely, and on saturating with sodium sulphate at $34^{\circ}$, the edestin is thrown down completely.

EDESTIN HYDROCHLORATES.

Monohydrochlorate.-If pure edestin, neutral to phenolphthalein, be dissolved in ten per cent. sodium chloride brine and gradually mixed with an equal volume of the same brine containing one cc. of decinormal hydrochloric acid for each gram of edestin, a nearly or quite clear solution is obtained, which, when dialyzed, yields a wholly crystalline deposit. On washing with water a part of this deposit dissolves after the salts have been removed, and a part remains undissolved being wholly insoluble in water. This latter substance is edestin monohydrochlorate.

When dissolved in brine, one gram of this salt is neutralized to phenolphthalein by seven-tenths $c c$. of decinornal alkali solution. Assuming that edestin has a molecular weight of about 14,300,' this body, insoluble in water, consists of one

1 The simplest formula for edestin (containing two atoms of sulphur) which can be calculated from the average of a large number of closely agreeing analyses (carbon, 51.55; hydrogen, 6.92; nitrogen, 18.67 ; sulphur, 0.90; oxygen, 21.96) gives a molecular weight of $7,13^{8}$, twice which is 14,276 , the formula being, carbon, 644 ; hydrogen, 988 ; nitrogen, Igo; sulphur, 4; oxygen, 196.

Calculation of similar formulas for plant globulius containing but four-tenths per cent. of sulphur shows that these substances, if there are two atoms of sulphur in the molecule, must have a molecular weight of not less than 14,500 . The same is true for globin from oxyhaemoglobin recently analyzed by schultz. closelyagreeing molecular weights for the more carefully aualyzed protein-bodies can be calculated from theit analyses by multiplying the simplest formula containing one atom of sulphur by such a factor that each formula shall contain two or more atoms of sulphur and have a molecular weight nearest to 15,000 . For twenty-seven distinct protein-bodies of vegetable and animal origin formulas strikingly similar to that above given for edestin are so obtained, and also molecular weights, nearly all of which are very nearly 15,000 , the extremes being 14,058 and 16,074 . Those protein substances know to be compound bodies, like oxyhaemoglobin and casein, give higher noleculat weights. The number of sulphur atoms in these formulas ranges from two to ten. One gram of substance having a molecular weight of 15,000 would require for a complete wolecular reaction $0.66 \mathrm{cc}$. of a decinormal solution. 
molecule of edestin combined with one molecule of hydrochloric acid.

When pure edestin is dissolved in ten per cent. neutral sodium chloride brine and the solution, which is neutral to phenolphthalein, is dialyzed, imperfectly developed crystals are deposited that, when dissolved in neutral brine, yield a solution having an acidity nearly or quite equal to that of edestin nonohydrochlorate.

Edestin monohydrochlorate is wholly insoluble in water, but dissolves in ten per cent. sodium chloride brine to a solution from which it is readily thrown down by adding water. On warming the thus diluted brine, the precipitate dissolves and reappears on cooling in octahedral crystals.

A solution containing five per cent. of edestin monohydrochlorate and ten per cent. of sodium chloride becomes turbid when heated to $95^{\circ}$, and a flocculent coagulum separates slowly on continued heating at $99^{\circ}$.

Edestin Bihydrochlorate. - When pure edestin is treated with insufficient dilute hydrochloric acid to dissolve it all, the part dissolved consists of bihydrochlorate of edestin. To neutralize to phenolphthalein one gram of edestin thus dissolved, one and one-fourth $\mathrm{cc}$. of decinormal alkali are required, and in the solution from which edestin is thereby precipitated, alkali chloride is formed very nearly equivalent to the alkali added.

Edestin bihydrochlorate is soluble in pure water, its solution therein being, however, precipitated by very small quantities of alkali salts. Although quite insoluble in one or two per cent. sodium chloride brine, edestin bihydrochlorate freely dissolves in ten per cent. salt solution.

From ten per cent. sodium chloride brine the bihydrochlorate separates on dialysis in octahedral crystals. By diluting its solution in ten per cent. brine a precipitate is formed, which dissolves on warming the diluted brine. On cooling, this solution deposits the substance in very perfect crystals.

The ten per cent. sodium chloride solution of edestin bihydrochlorate, like the similar solutions of the monohydrochlorate and of edestin, gives, when saturated with sodium chloride, a very slight precipitate; when saturated with magnesium sul- 
phate, somewhat more, and saturated at $34^{\circ}$ with sodium sulphate is completely precipitated.

A solution containing ten per cent. of sodium chloride and ten per cent. of edestin bihydrochlorate gives a slight precipitate when mixed with one-half its volume of water, and a rapidly increasing precipitate on continued dilution.

A solution containing ten per cent. of sodium chloride and five per cent. edestin bihydrochlorate gives a slight precipitate with an equal volume of water. When heated in a double water-bath, ten per cent. salt solution containing five per cent. of edestin bihydrochlorate becomes turbid at $90^{\circ}$ and at $9 \mathrm{I}^{\circ}$ flocks separate, which gradually increase in quantity on heating at $99^{\circ}$. Edestin bihydrochlorate dissolved in water or salt solution reacts acid to phenolphthalein and litmus, but is strongly alkaline to lacmoid.

When the solution of edestin bihydrochlorate in water is made neutral to phenolphthalein, by addition of alkali, the edestin separates out completely and is then almost entirely soluble in ten per cent. brine.

From the water solution of edestin bihydrochlorate the edestin is completely thrown down by small quantities of soluble saits; but this precipitate is not wholly redissolved by ten per cent. brine, a relatively small portion remaining insoluble, which is more acid than edestin bihydrochlorate while the substance redissolved is less acid and shows the properties of a mixture of the mono- and bihydrochlorate.

OTHER ACID SALTS OR DERIVATIVES OF EDESTIN.

I. The substance insoluble in ten per cent. solution of sodium chloride, last mentioned in the preceding paragraph, is or contains a third more acid compound or derivative of edestin, which on neutralization yields a product wholly different from edestin, which is now under investigation. Its study is expected to throw light on the nature of "acid albumin" and of Weyl's "albuminate."

2. All edestin preparations, obtained from sodium chloride extracts of hemp-seed by dialysis or by cooling, when dissolved in a minimum of hydrochloric acid, react so strongly alkaline 
with lacmoid' that a total of from two and five-tenths to three cc. of decinormal acid are required to neutralize to lacmoid the solution of one gram of edestin, and to obtain an acid reaction with this indicator a total of about eleven cc. of acid per gram are necessary.

3. On treating several gram portions of edestin with uniformly increasing quantities of decinormal hydrochloric acid and testing for free acid with mixed potassium nitrite, iodide and starch paste, a very marked difference was seen in the intensity of the reaction, between six and five-tenths cc. of decinormal acid per gram or less, and seven cc. or more, strongly indicating a firmer binding of the smaller quantity of acid.

4. With tropæolin no reaction for free hydrochloric acid could be obtained until thirteen cc. of decinormal acid had been added, a quantity just twice that found in testing for free acid with potassium nitrite.

Closely agreeing figures are given by this indicator, and different preparations of the same protein body have given accordant results; thus, three different samples of edestin reacted with $\mathrm{r} 2.9 \mathrm{cc}$., $\mathrm{r} 2.5 \mathrm{cc}$, and $\mathrm{I} 2.7 \mathrm{cc}$.

Many other protein preparations thus tested have shown that from nine to thirteen $\mathrm{cc}$. of acid are bound by one gram of substance. Excelsin fixed I2.4 cc.; legumin from three different seeds fixed $12.5 \mathrm{cc}$., I $2.9 \mathrm{cc}$, and $\mathrm{I} 3.4 \mathrm{cc}$; amandin took up IO. $3 \mathrm{cc}$ and crystallized egg albumin $9 \mathrm{cc}$.

Whether the results of the interaction of edestin with these larger quantities of hydrochloric acid are simply edestin salts, or products of its decomposition or alteration, is as yet undetermined.

Edestin forms soluble compounds with nitric and acetic acid in the same molecular proportions as with hydrochloric acid.

When former edestin preparations (separated from salt solution by dialysis), which yield on neutralization chlorides, sulphates, in some cases traces of phosphates, and always more or less organic matter, are suspended in water and treated with measured amounts of hydrochloric acid (not in excess), they dissolve in proportion to the quantity of acid added, provided the amounts of water-soluble substance (bi-acid edestin) orig-

1 Blood, milk and other animal fluids, as well as saline extracts of seeds, react strongly alkaline with lacmoid. This reaction, though doubtless due to some extent to alkaline phosphates, is unquestionabiy chiefly caused by the protein constituents of the fluid. 
inally contained in the preparations be deducted from the total quantities dissolved. Thus, several series of determinations of the solubility of edestin were made by suspending gram portions in water enough to make a final volume of twenty $c c$. and adding successively increasing quantities of centinormal hydrochloric acid. After frequently shaking during several hours, the solutions were allowed to settle, filtered clear, the acidity to phenolphthalein determined, the solutions evaporated, the residues dried at $110^{\circ}$ and weighed.

It was found that the amount of edestin thus dissolved increases quite uniformly with increased quantity of acid, and that a little over 0. I gram of the substance is carried into solution by each additional cc. of centinormal hydrochloric acid. The acidity of the soluble body thus produced is very nearly that of a compound of edestin with two molecules of monobasic acid.

Those preparations which yield relatively much alkali sulphate on neutralization are less soluble in hydrochloric acid than the others, and the water-soluble edestin compounds resulting are relatively more acid, since pure edestin requires for solution more sulphuric than hydrochloric acid, and the soluble edestin sulphates are much more acid than the soluble bihydrochlorate. All the preparations of edestin whose solubility in hydrochloric acid we have determined yield more or less alkali sulphate on neutralization. To this fact we attribute the slightly less degree of solubility in hydrochloric acid found than that calculated for a compound of two molecules of acid with one of edestin (molecular weight assumed to be 14,300 ), and also the correspondingly slightly greater acidity of the dissolved substance.

Edestin Sulphates.-Determinations of the solubility in sulphuric acid of edestin give tolerably uniform results for one and the same preparation, but differ for different preparations. With increasing quantities of sulphuric acid the degree of acidity of the soluble products increases uniformly up to many times that of the bihydrochlorate. This behavior with sulphuric acid is due to the fact that the preparations tested were largely hydrochlorates. Definite results cannot be had until preparations free from acids other than sulphuric have been made and tested, which work we now have in hand. 
What has been said of sulphuric acid applies, though to a less degree, to phosphoric acid, a centinormal solution of which dissolves about one third as much edestin as a like solution of hydrochloric acid. In other words, tribasic phosphoric acid in dissolving edestin appears to act as a monobasic acid.

A study of the relations to bases and acids exhibited by many other protein substances is in progress, the results of which will be published soon. So far as yet discovered, all other protein preparations are compounds of a similar character to those of edestin. Although much evidence to this effect has been obtained, details are reserved until the entire accuracy of the results is confirmed and the study extended so that it may be made more complete.

It is unnecessary to point out the importance of the fact that what have been heretofore regarded as "native" protein substances are, in fact, protein bodies combined to acids, so that preparations as usually obtained have been mixtures of the simpler salts of these bodies. In this fact we will doubtless find an explanation of many of the minor differences noted between protein preparations which appear to be otherwise identical. Thus, the difference between the albumins of the eggs of different kinds of birds, between the haemoglobins of the blood and the caseins of the milk of different animals may well be thus explained.

Courrant's studies of the proportion of alkali and acid neutralized by casein makes it seem highly probable that nucleoalbumins will prove to be phosphoric acid compounds similar to those described in this paper, but containing several molecules of acid.

Fuerth's account of the protein bodies of the muscle plasma indicates that the confusion which has existed in relation to these substances is probably due to the formation during extraction and separation of a series of increasingly acid compounds of one or more protein bodies. The sensitiveness of many enzymes to alterations in reaction is not improbably connected with the formation of definite acid compounds.

The unexplained, apparently spontaneous, alteration of protein substances is in many cases certainly due to the formation of acid compounds. 